\title{
Synthesis
}

\section{Altered Ecological Flows Blur Boundaries in Urbanizing Watersheds}

\author{
$\underline{\text { Todd R. Lookingbill }}^{1}$, Sujay S. Kaushal ${ }^{1}$, Andrew J. Elmore ${ }^{1}$, Robert Gardner ${ }^{1}$, Keith N. Eshleman ${ }^{1}$, \\ Robert H. Hilderbrand ${ }^{1}$, Raymond P. Morgan ${ }^{1}$, Walter R. Boynton ${ }^{1}$, Margaret A. Palmer ${ }^{1}$, and \\ William C. Dennison ${ }^{1}$
}

\begin{abstract}
The relevance of the boundary concept to ecological processes has been recently questioned. Humans in the post-industrial era have created novel lateral transport fluxes that have not been sufficiently considered in watershed studies. We describe patterns of land-use change within the Potomac River basin and demonstrate how these changes have blurred traditional ecosystem boundaries by increasing the movement of people, materials, and energy into and within the basin. We argue that this expansion of ecological commerce requires new science, monitoring, and management strategies focused on large rivers and suggest that traditional geopolitical and economic boundaries for environmental decision making be appropriately revised. Effective mitigation of the consequences of blurred boundaries will benefit from a broad-scale, interdisciplinary framework that can track and explicitly account for ecological fluxes of water, energy, materials, and organisms across human-dominated landscapes.
\end{abstract}

Key Words: catchment ecology; Chesapeake Bay; interdisciplinary science; large river; Potomac River; restoration; urban metabolism

\section{INTRODUCTION}

The magnitude and intensity of human activities affect ecological processes at spatial scales that extend far beyond the urban footprint (Lankao 2004), making landscape alteration a primary threat to the sustainability of the Earth's biosphere (Schröter et al. 2005). Although the direct effects of urbanization on stream ecosystems have been widely documented (Paul and Meyer 2001, Walsh et al. 2005), anticipating the indirect and interactive effects of the broad-scale degradation of ecosystem functions and services remains a challenge (Goetz et al. 2004). This challenge is amplified by an inability to fully account for the cumulative influences of human actions because of the fine spatial scales of most ecosystem investigations.

Ecological studies have tended to take a limited view of land-use change, with watersheds and ecosystems defined as discrete, clearly demarked units, and human actions considered as disturbances rather than intrinsic system components. This narrow focus lacks sufficient perspective to allow understanding and management of the consequences of change at the landscape scale. In response, there has been renewed interest in a broader, more integrative approach to the study of ecosystem processes (Pickett et al. 2001, Nilsson et al. 2003, Turner 2005). As one specific example, natural resource managers must now account for the significant movement of organisms, materials, and energy across traditional landscape boundaries such as the small watershed (Hatch et al. 2001, Magner and Brooks 2008).

The importance of carefully matching conceptual ecosystem boundaries to the processes being studied and the implications of mismatching these scales have been highlighted recently for geomorphic, hydrological, and ecological processes (Post et al. 2007, Peters et al. 2008). Disciplinary biases have hindered these efforts by relying on data for which the scale is primarily determined by logistical instrumentation and sampling constraints, rather than ecological first principles. We argue that many traditional boundaries within and among stream catchments have become artificial constructs that are being blurred by changes associated with human modifications of the landscape. We define this 
blurring as an increase in connectivity among the river, its uplands, and increasingly distant regions of the landscape, region, and world. An explicit accounting of these cross-boundary transfers should be an important component of any watershed management strategy. We describe patterns of landuse change and human activities within the Potomac River basin and provide examples of how these changes act to increase the mobility of water, energy, materials, and organisms into and within the basin. These observations can be used to promote future research, develop monitoring priorities, target management needs, and anticipate the effects of increasing rates of urban-suburban development.

\section{THE POTOMAC RIVER BASIN}

Large river ecosystems, which drain vast regions and transport sediments, nutrients, chemicals, and biota over long distances, can provide an integrative measure of the impact of social, economic, and ecological change (Walling and Fang 2003). The Potomac River basin (PRB; Fig. 1) provides an illustrative example because of its setting within a landscape continuum from mountains to sea; its geomorphic and land-use diversity; its importance as habitat for a diverse biota; its location on the boundary between the humid continental and humid subtropical climate zones; and the dependence of the United States' capital region on the river as a water supply (Cohn 2004). It is located in one of the most rapidly urbanizing regions of the United States and provides a natural experiment with regard to humans as part of ecosystems and the resulting transfers across hydrological boundaries. The Potomac River is also one of the main tributaries to Chesapeake Bay, the largest estuary in the United States, supplying $17 \%$ of its mean annual freshwater input. Consequently, the water quality of this river is a key factor determining sediment, nutrient, and freshwater loads to the bay. Billions of dollars have been spent on efforts to reduce tributary pollution and related nutrient loading to the bay, with equivocal success (Boesch and Greer 2003, Hassett et al. 2005).

The $617-\mathrm{km}$ main stem of the Potomac is relatively unregulated as it flows through the five physiographic provinces of the eastern seaboard: Appalachian Plateau, Ridge and Valley, Blue Ridge, Piedmont, and Coastal Plain. The river drains approximately $37,800 \mathrm{~km}^{2}$ of Maryland, Pennsylvania, Virginia, and West Virginia. More than 5.3 million people live within the basin (United States Census Bureau 2000), with approximately 3.7 million residing in the urban matrix surrounding Washington, D.C., and an influx of more than 1 million additional residents projected by 2020 (Fig. 2 ). The PRB has a long history of land-use change (Barnhart 1931, Otterstrom 2003, Sprague et al. 2006), with contemporary trends being regionally variable. Coal mining is the most significant driver of change in the Appalachians; large tracts of agricultural land are being developed into suburban areas in the Ridge and Valley; and the Piedmont and Coastal Plain continue to be urbanized. The historical patterns of human settlement that have led to this mixture of land uses have had a profound effect on the scale of human effects on the river resource.

Since the 1600s, the PRB has moved through four well-documented stages of land-use change (Lankao 2004, Foley et al. 2005, Mustard et al. 2005). The first was the Frontier stage, during which natural resource use was primarily in the form of local deforestation to provide fiber and land for further development. Because of its colonial status and rapidly developing economy, the Potomac Frontier stage quickly transitioned into the Agricultural Expansion stage (Benitez and Fisher 2004). Agriculture has a rich history in the PRB and continues to influence public land-use policy today. During the subsequent Industrialization/Urbanization stage, the agricultural area stabilized as land resources and economic interests became focused on industrial production in the western portion of the basin and continued development of urban centers in the east. It is worth noting that the city of Washington, D.C., is somewhat unusual in that it is supported by a governmental apparatus and has never been as reliant on an industrial base as other cities in the region. Nevertheless, the shift from forest-dominated to agricultural to mixed-use landscape experienced in the PRB is representative of patterns of change occurring throughout the industrialized world (Fig. 3A).

During the fourth stage, Post-industrial Revolution, there has been a stabilization of forested land cover, but continued urban development throughout the PRB (Sprague et al. 2006). After World War II and into the 1970s, growth was greatest near city centers and radiated out in concentric rings from Washington and Baltimore (Morrill 2006). However, growth in the last few decades has largely occurred in dispersed pockets away from the city 
Fig. 1. Land-cover map of the Potomac River watershed. Classification is based on 2000 Mid-Atlantic Regional Earth Science Applications Center land-cover mapping of the Chesapeake Bay watershed. The percentage of watershed in each cover category is provided in the legend. The triangle indicates the location of the Point of Rocks monitoring station; the circle indicates the approximate location of the Washington, D.C., withdrawal site near Little Falls. PA, Pennsylvania; MD, Maryland; WV, West Virgina; DC, Washington, D.C.; VA, Virgina.

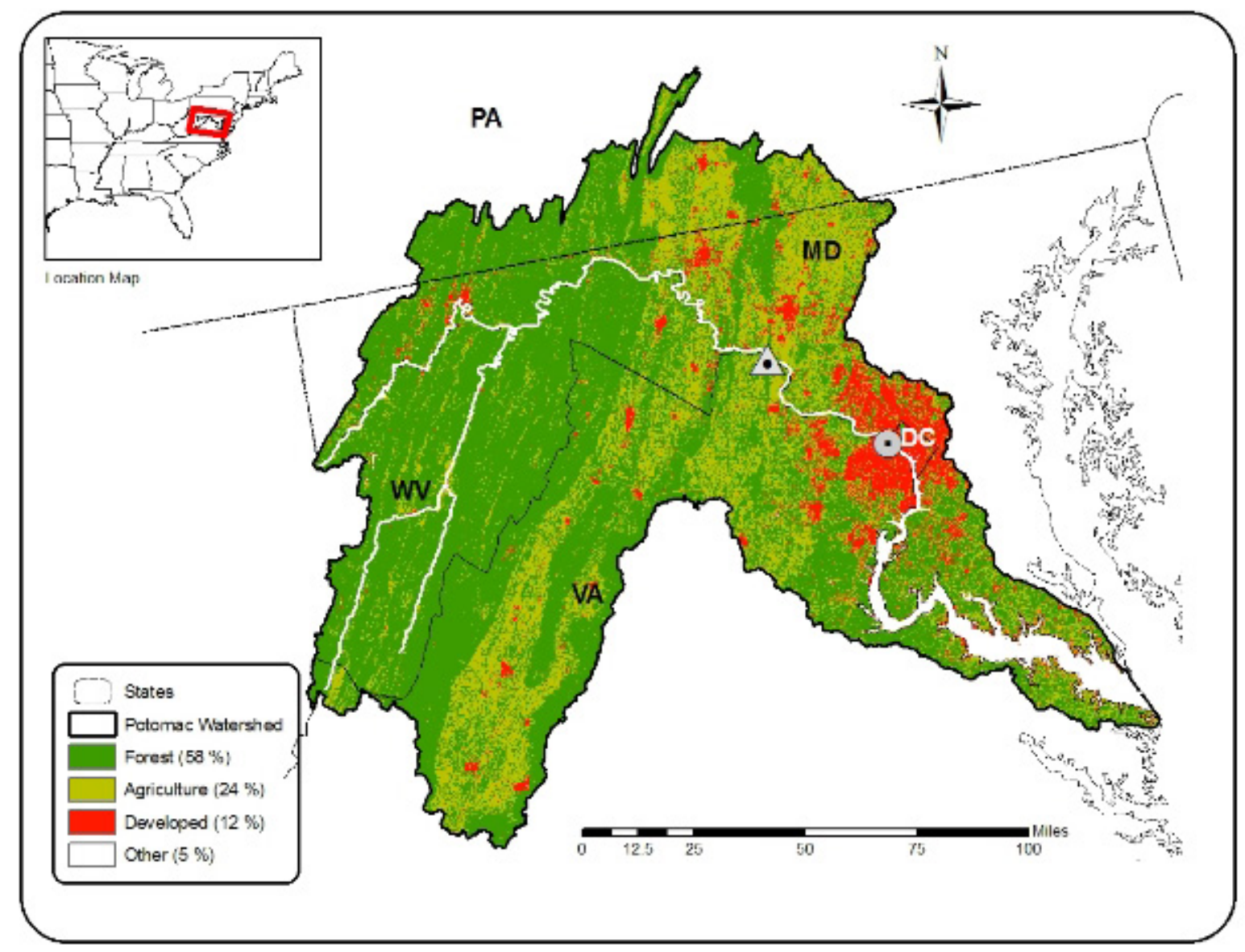

centers (Irwin and Bockstael 2002). This dispersed growth, or exurban sprawl, is characterized by scattered residential development in outer suburban and urban-rural fringe areas (Galster et al. 2001). As in other parts of the United States (Theobald 2001), much of the sprawl has radiated from nodes centered on or in close proximity to natural resource amenities. Thus, in addition to their historical roles as dominant cultural and transportation corridors (Barnhart 1931, High 1997), large rivers such as the Potomac offer a useful unit of aggregation for examining contemporary housing preferences of modern home owners.

\section{CONSEQUENCES OF CHANGE: PEOPLE AND MATERIALS ARE INCREASINGLY MOBILE}

These land-use changes have had profound consequences on the speed and magnitude of transfers of energy, nutrients, and water into, out of, and within the watershed. The enhancement of lateral fluxes across the landscape, which is little studied and difficult to measure, can lead to distinct biogeochemistry and hydrology that differs from other impacts of land-use/land-cover change. In short, we live in an increasingly interconnected 
Fig. 2. Urban development as of 2001 (gray) and projected for 2020 (black) in central Maryland and northern Virginia. Projected urban development provided courtesy of D. M. Theobald, Colorado State University.
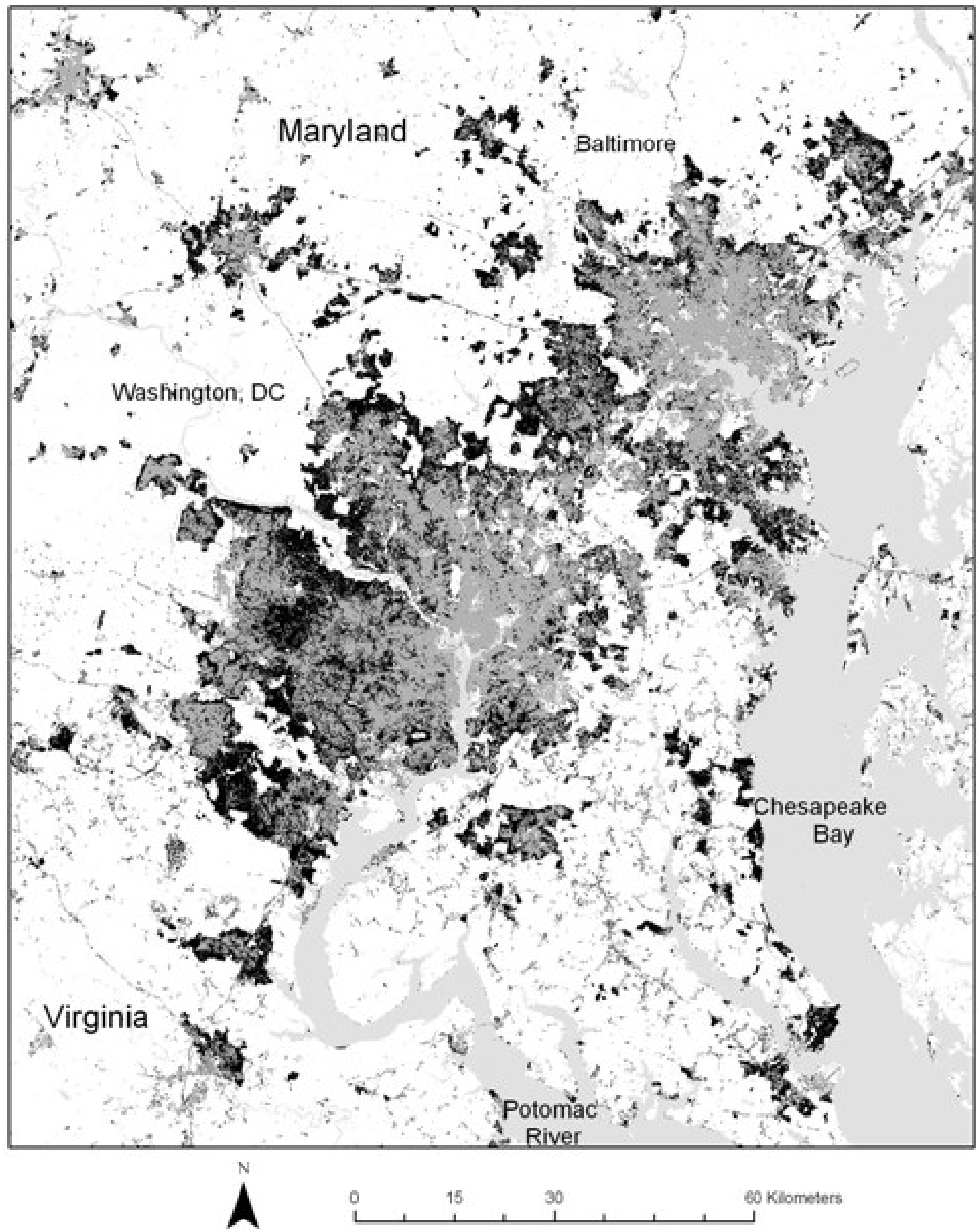
Fig. 3. (A) Land-use change in large river basins such as the Potomac River watershed can be characterized by four stages: frontier, agricultural expansion, industrial urbanization, and post-industrial economy. (B) Conceptualized scale of nutrient cycling as a function of four stages in land-use change: from the frontier era in the 1600s, when nutrient cycles were well bounded by small watersheds, to the current post-industrial era, which is characterized by increasing urbanization and large-scale (up to global) nutrient fluxes.
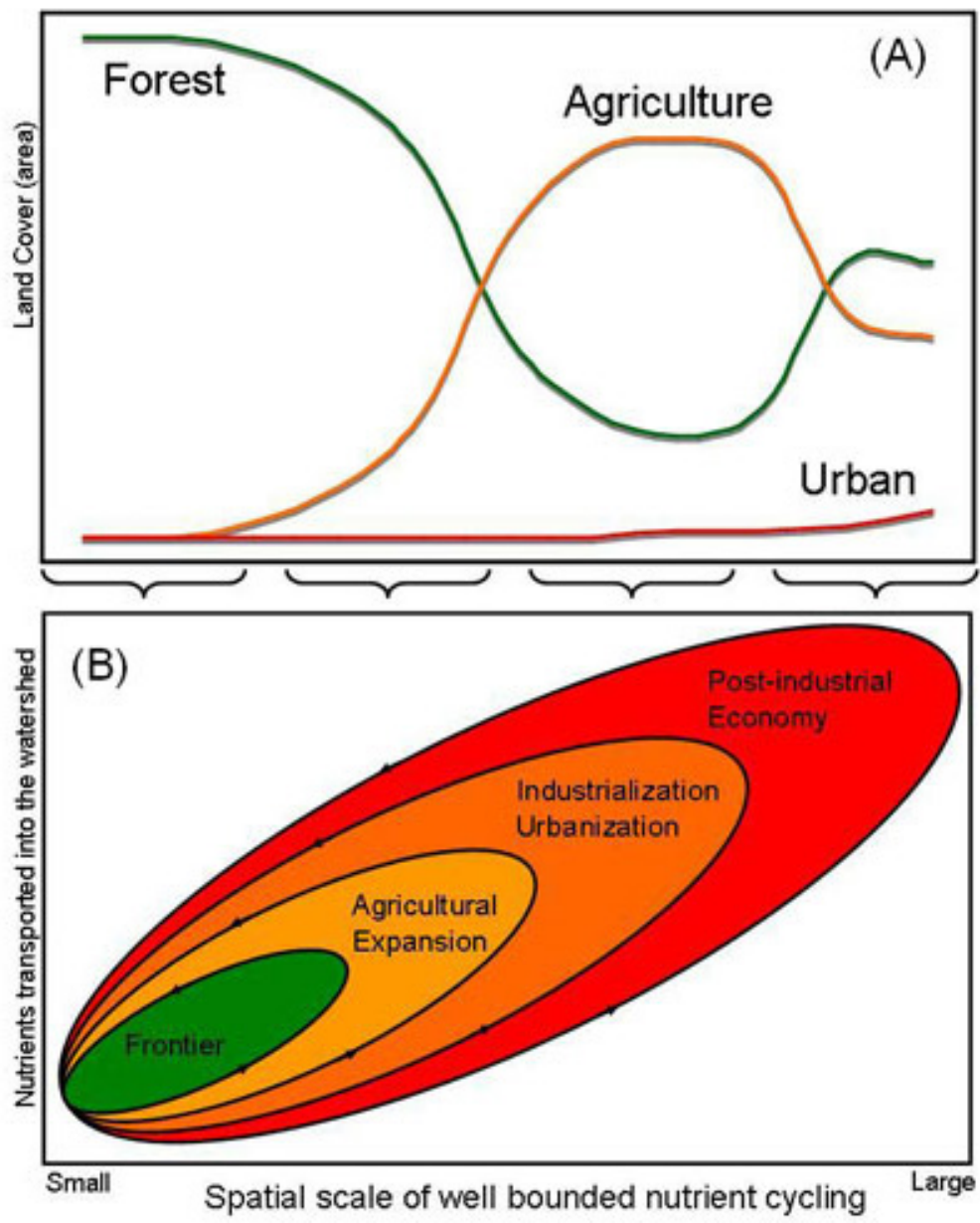

world, and the consequences of this connectivity are as profound for the environment as they are for business, politics, or communication. This increasing connectivity among distant regions is the focus of a recent series of publications that describe the importance and challenges of continental-scale environmental studies (e.g., Peters et al. 2008, Williamson et al. 2008). Here, we show how the increasing connectivity of ecological commerce is not limited to the continental scale, but applies across a wide range of spatial scales. The combined influence of these transfers has important consequences to water quality goals in receiving estuaries such as Chesapeake Bay.

\section{Urban basins import resources from global sources}

The environmental ramifications of enhanced connectivity began when the first human society determined that it was necessary to leave its local 
watershed in search of resources and thus expand its ecological footprint (Wackernagel and Ress 1996, Meyerson et al. 2007). Because these resources were transported back into the original watershed, the spatial scale of changes in nutrient cycling was increased (Fig. 3B). During the Frontier stage of land-use development, humans transported few nutrients into the PRB. However, during Agricultural Expansion, nutrients were acquired from many different regions, including fish tissue from Chesapeake Bay and coastal systems, bird guano from the Caribbean islands, and mineral deposits from eastern North America (Mikkelsen and Bruulsema 2005). With the development of synthetic fertilizers in the mid-1900s, the scale of nutrient transport was effectively made global, and the PRB became a loosely bounded system with respect to nutrients (Jordan and Weller 1996). The practice of sending urban sewage to local farmlands and the subsequent recycling of nutrients was discontinued abruptly in the 20th century with the development of the modern fertilizer industry (Wines 1985). Therefore, the transition from Frontier to input-oriented Industrial Revolution resulted in a dramatic enlargement of the ecological system and a corresponding increase in the quantity of nutrients humans transported into the PRB.

The Post-industrial economy of the PRB has been characterized by a change in the form of imported nutrients, rather than a change in the magnitude of imports. Since the Industrial Revolution, decreases in agricultural area have been balanced or exceeded by increases in imports of food for livestock and human populations. Food imports are a major component of the nitrogen budget for the PRB, which has the highest net import of food and animal feed of the major tributary basins of Chesapeake Bay (Boyer et al. 2002; Table 1). Nitrogen imports to the basin from these sources are nearly double those from atmospheric sources (Table 1). Animals and humans process foods into forms that are highly polluting of surface and groundwater systems. This problem is exacerbated for basins like the PRB that have housing dominated by single-family homes that rely on septic systems that are not connected to municipal wastewater facilities (Wernick et al. 1998, Kaushal et al. 2006). The increase in food imports can be seen directly in nutrient balance models that demonstrate that the largest source of nitrogen for the Potomac River is now from animal waste (Jaworski 1990, Jaworski et al. 1992, Jaworski et al. unpublished manuscript http://www. umces.edu/president/Potomac). Regionally, the production and discharge of sewage has become one of the largest sources of reactive nitrogen in watersheds of the northeast United States (Driscoll et al. 2003). As a consequence, household dietary choices have been shown to have a profound effect on fluxes of carbon, nitrogen, and phosphorus (Baker et al. 2007). Increasingly, these choices are not from local sources.

Modern U.S. cities exhibit particularly high per capita nutrient metabolism relative to their international counterparts. Kennedy et al. (2007) assembled data on overall fluxes of nutrients, water, energy, and materials for eight non-U.S. megacities (i.e., cities with populations $>1$ million), and compared these fluxes with those reported by Wolman (1965) in his study of urban metabolism for U.S. megacities, including Washington, D.C. A general trend of increasing per capita metabolism was observed over the past several decades, but most international cities have yet to reach the high input rates, especially for freshwater and energy, observed for the 1960s sample of U.S. cities. Kennedy et al. (2007) noted the relatively low population densities of U.S. cities as a potential explanation for the greater per capita energy consumption (see also Kenworthy and Laube 1999). In other words, the patterns of sprawl indicative of urban expansion in the United States (Figs. 1 and 2) require significant investments in transportation energy and result in significant resource flows between cities and their surrounding hinterlands. These relationships are strongest when residential homes are separated by long distances from employment centers, as they are in the PRB (Miller and Ibrahim 1998).

The concept of virtual water provides another method for quantifying the exchange of water resources across international boundaries. Virtual or embedded water measures the amount of water required to produce an item at its point of origin (Allan 1998). The United States is by far the largest consumer of virtual water, with a water footprint of $2480 \mathrm{~m}^{3}$ person ${ }^{-1} \mathrm{yr}^{-1}$, or twice the global per capita average (Hoekstra and Chapagain 2007). The vast majority of this water is attributable to the consumption of agricultural goods, especially meat products; a hamburger costs approximately 20 times more water to produce than a potato. As urban basins like the PRB become more affluent, their water footprints tend to expand, reaching out into agricultural regions across the world. Currently, $18.4 \%$ of U.S. virtual water is supplied by 
Table 1. Overall nitrogen budget for the Potomac River basin and the four major tributary basins of Chesapeake Bay. The Potomac River basin has the largest net nitrogen (N) import in food and animal feed of the four major tributaries.

\begin{tabular}{lcccccc}
\hline \hline $\begin{array}{l}\text { Tributary basin of } \\
\text { Chesapeake Bay }\end{array}$ & $\begin{array}{c}\text { Net atmospheric } \\
\text { N deposition }\end{array}$ & N fertilizer use & $\begin{array}{c}\text { N fixation } \\
\text { in } \\
\text { forestlands }\end{array}$ & $\begin{array}{c}\text { N fixation in } \\
\text { agricultural lands }\end{array}$ & $\begin{array}{c}\text { Net N } \\
\text { import in } \\
\text { food and } \\
\text { feed }\end{array}$ & Total N inputs \\
\hline Potomac & 769 & 1024 & 271 & 1173 & 1452 & 4689 \\
Susquehanna & 1138 & 615 & 179 & 1147 & 1095 & 4173 \\
Rappahannock & 893 & 1030 & 277 & 1439 & 607 & 4246 \\
James & 953 & 361 & 361 & 703 & 395 & 2773 \\
\hline
\end{tabular}

Note: Units for inputs and exports of nitrogen are $\mathrm{kg} \mathrm{km}^{-2} \mathrm{yr}^{-1}$. All data are from Boyer et al. (2002).

international sources (Hoekstra and Chapagain 2007). Thus, the trends in land-use change experienced in the PRB influence not just nutrient cycles as food, fertilizer, and animal feed are imported into the basin (Fig. 3), but industrialized megacities can also influence water cycles thousands of kilometers away as water is redirected to agricultural fields to meet virtual water demands.

\section{Humans facilitate water and nutrient movement within large basins}

Although nutrients and water continue to flow across boundaries of large river basins, major rivers such as the Potomac still act as integrators of the terrestrial and aquatic metabolic changes imposed by human activities. Within these basins, patterns of urbanization and sprawl have produced new patterns of ecological commerce as people and materials flow from food and water production centers to residential hubs to business centers. For example, human waste pollutants are not limited to those stemming from the home. A growing body of research suggests that biologically mediated transport can be an important and typically unconsidered vector for pollutant transport (Blais et al. 2007). In particular, social animals, including humans, that bioaccumulate contaminants and then migrate to and congregate in new locations can become a primary vector for contaminant spread.
In large, urbanizing watersheds such as the PRB, the daily movement of humans represents a chronic transfer of materials and energy across watershed boundaries. The combination of soaring housing costs and loss of jobs in rural communities has fostered suburban development and forced people to commute increasing distances to work (Preuss and Vemuri 2004, Sultana and Weber 2007). The mean travel time to work for the state of Maryland has reached more than 30 minutes (United States Census Bureau 2000), and many cities on the Potomac River experience large daily population swings caused by this influx of commuters. Washington, D.C., shows a $73 \%$ increase in its population during the daytime because of commuters working in the city. In addition to transportation-related nitrogen emissions added to the watershed by these commuters, the commuters are also transferring a great deal of waste products. Assuming that humans process approximately 4.8 $\mathrm{kg} / \mathrm{yr}$ of nitrogen (e.g., Valiela et al. 1997, Kaushal et al. 2006) and that $50 \%$ of the nitrogen from commuters is released during the workday, this would constitute a net flux of $0.98 \times 10^{6} \mathrm{~kg} / \mathrm{yr}$ of nitrogen just from the production of human waste by commuters.

It could be argued that this substantial transfer of nutrients from residential to urban regions of the basin could be discounted because human wastes are well-treated point sources. However, at least 
three factors point to the reduced effectiveness of this treatment in the urban environment. First, aging infrastructure in older cities like Washington, D.C., has numerous sewage leaks that transport nonpoint nitrogen to streams (Groffman et al. 2004). Second, older cities like Washington, D.C., have combined sewer overflows, and the mixing of stormwater and sewage nitrogen during storm events can further elevate and amplify the wastewater nitrogen flux (Kaushal et al. 2008a). Third, new regulations, triggered at least in part by the strain of dealing with the increased inputs from commuters, are under consideration and would require costly improvements to wastewater treatment plants to further reduce bioavailable nitrogen loads in effluent to Chesapeake Bay.

The lateral transfer of water and associated materials via broad-scale networks of pipes and other human engineered systems compose another major transport vector in large basins. In particular, the concentrated diversions of water to support extensive drinking water and sanitation networks can have important ecological ramifications for reaches downstream of major intakes and outfalls (Postel et al. 1996, Postel 2000). These transfers can have significant effects on both receiving waters and the systems from which water is removed, particularly under low flow conditions. The PRB provides illustrative examples of both of these phenomena.

Minimum flows for two gaged headwater tributaries of the PRB exemplify the effect of flow augmentation related to transfers between small watersheds. Savage River drains a $127 \mathrm{~km}^{2}$ predominantly forested drainage basin in western Maryland that is virtually free of any major diversions, whereas Wills Creek drains a $640 \mathrm{~km}^{2}$ rural drainage basin located in western Maryland and south-central Pennsylvania that receives drainage from the Hoffman Drainage Tunnel. This tunnel was constructed in the early part of the 20th century as a gravity drain of underground coal mine workings and still functions as a diversion of water from the adjacent Georges Creek watershed into Wills Creek. The cumulative distribution of sevenday annual low flows for the two streams based on 61 years of continuous U.S. Geological Survey daily discharge records illustrates that seven-day low flows, normalized by watershed area, are significantly higher in Wills Creek than in Savage River owing to flow augmentation from the Hoffman Tunnel. Moreover, the 7day-Q10, i.e., the seven-day low flow not exceeded in $10 \%$ of years, for Wills Creek of $0.057 \mathrm{~mm} / \mathrm{d}$ is nearly three times higher than the value of $0.015 \mathrm{~mm} / \mathrm{d}$ predicted using a regional equation developed by U.S. Geological Survey (Carpenter and Hayes 1996) for streams in western Maryland. For the Savage River station, in contrast, the measured and predicted values of 0.022 $\mathrm{mm} / \mathrm{d}$ and $0.024 \mathrm{~mm} / \mathrm{d}$, respectively, are nearly identical (Fig. 4A).

Reaches below Little Falls Dam on the lower, nontidal Potomac River are also affected by a major transfer between watersheds; in this case, a portion of the flow into the reach above Little Falls Dam is diverted by the Washington Aqueduct to provide a substantial percentage of the drinking water for the Washington, D.C., metropolitan area. A comparison of the cumulative distributions of seven-day low flows above and below the intake illustrates this situation. As expected, the reduction of flow caused by this withdrawal of approximately $0.04 \mathrm{~mm} / \mathrm{d}$ is nearly constant along the entire distribution, but is proportionally most significant at the lower end of the distribution. This withdrawal contributes to a nearly $50 \%$ decrease in the seven-day low flow at the $10 \%$ exceedance level (Fig. 4B).

Two basin-wide analyses of water supplies and demands for the Potomac River (Hagen and Steiner 2000, Steiner et al. 2000) provide a rather sobering view of water resources in the basin over the next 35 years. These studies predict that future basinwide demands for surface water will substantially increase the number of days that water will need to be released from upstream storage to meet downstream demand. A frequency analysis of low flows in the Potomac River, upstream at Point of Rocks Maryland station, from 1896 to the present reveals that although the annual 30-day mean low flow has never actually dipped below the mean annual aqueduct diversion of 1.8 billion liters/day, this diversion represents at least $50 \%$ of the upstream flow in $13 \%$ of years (Fig. 5A). Projected increases in metropolitan water demand associated with population growth will further exacerbate the effects of water withdrawals from the river during low flow conditions. An examination of Washington, D.C., co-op system water supply and demand records from 1995 to 2004 illustrates a strong negative correlation between these two variables, i.e., demand increased during periods of low upstream flow (Fig. 5B). Thus, population expansion in the lower portion of the basin will require increasing management of upstream flows in years to come. 
Fig. 4. Cumulative distributions of measured seven-day annual low flows for several stations in the Potomac River Basin. (A) Two headwater tributaries. Solid line: Savage River (U.S. Geological Survey station 1596500); broken line: Wills Creek (U.S. Geological Survey station 1601500). Points were estimated using the empirical model of Carpenter and Hayes (1996). Solid circle: Savage River; open circle: Wills Creek. (B) Potomac River near Washington, D.C. Solid line: unadjusted data (U.S. Geological Survey station 1646500); broken line: adjusted data (U.S. Geological Survey station 1646502).
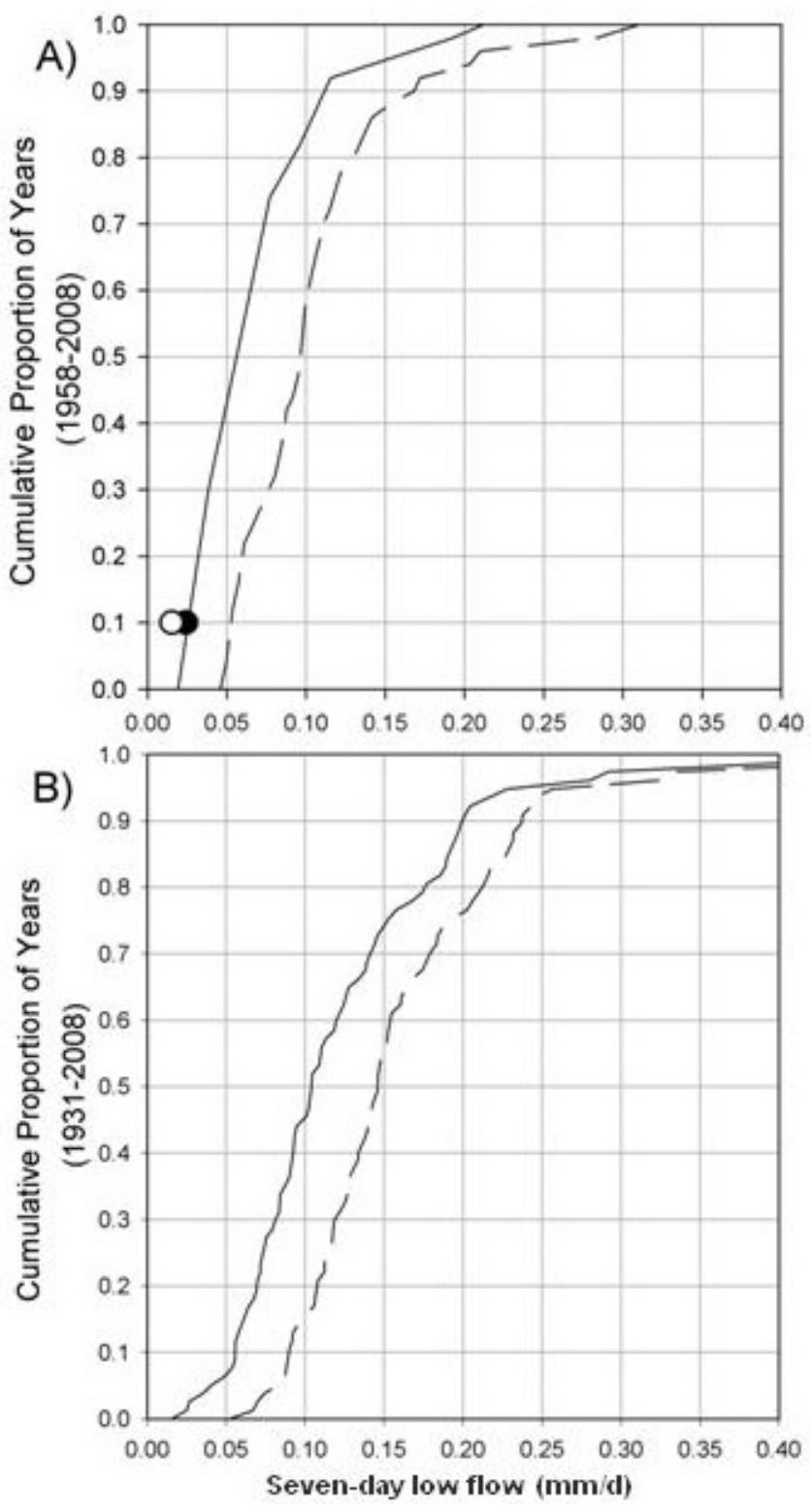
Fig. 5. The Potomac River at Point of Rocks (see Fig. 1) has a long hydrological record with which to characterize low river flow conditions. (A) Statistical analysis of the 30-day low-flow time series shows extreme low flow conditions occur in $13 \%$ of the 112 years of records, requiring water release from upstream reservoirs. (B) Peak system water demand occurs during these low flow periods, which means that continued population growth in the lower portion of the basin will require increasingly more manipulation of flows in the upper portion of the basin. BLD = billion liters/day.

(A)

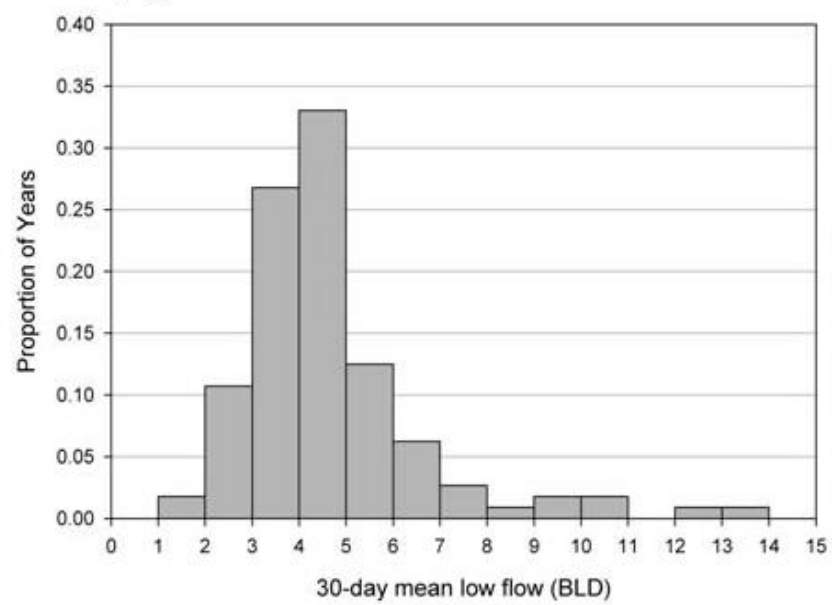

(B)

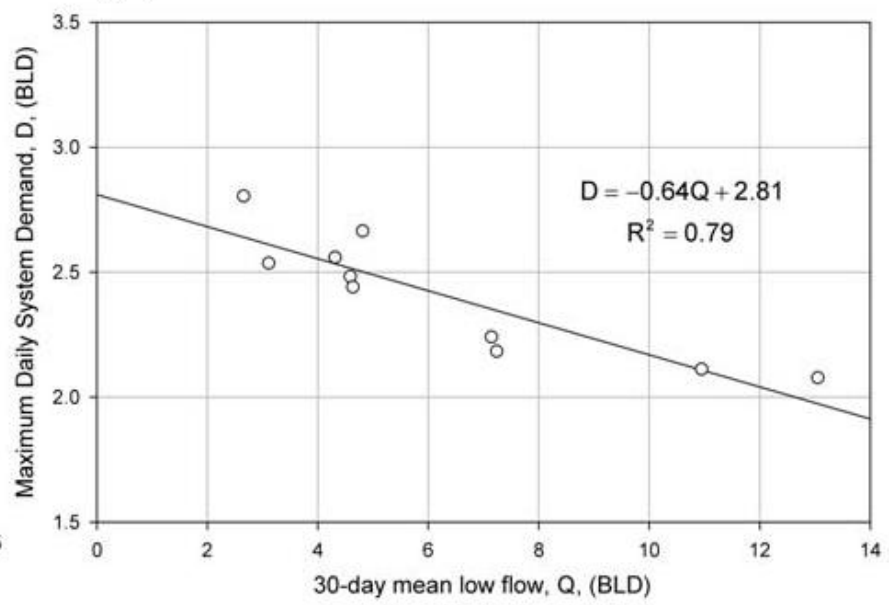

Several reviews have documented the hydrological connectivity between the management of headwater streams and downstream waters (Alexander et al. 2007, Nadeau and Rains 2007). In the PRB, this includes a review of the effects of basin-wide pesticide management on drinking water quality for Washington, D.C. (Ator et al. 1998). Pesticide detection in streams of the PRB has occurred mainly during periods of base flow when flow is mostly from groundwater sources. Again, the effect of interbasin transfers need to be considered. In early stages of development, communities often use local groundwater to supply household and light industrial needs, lowering base flow in urban streams (Simmons and Reynolds 1982). As water needs increase in urban centers, municipal water supply reaches further out into adjacent watersheds, which tend to be more agricultural and the sources of a variety of organic compounds. These interbasin transfers may also influence urban stream base flow in unintuitive ways. As water is brought into the urban environment, septic systems are not always replaced with municipal waste water systems. This, in combination with leaky supply pipes, often leads to significant increases in supply to groundwater systems (Kennedy et al. 2007). Therefore, during various stages of urbanization involving differing amounts of interbasin transfers of water and waste water infrastructure, urbanization can either decrease or increase base flow in streams (Brandes et al. 2005).

\section{Land-use change bypasses and deteriorates the terrestrial-aquatic interface}

The hydrological effects of urbanization at the local scale are under continuous study, and specific patterns have emerged that are directly relevant to the PRB. The conversion of forests and agriculture to urban and suburban development affects aquatic conditions through direct inputs of nutrients and water and loss of vegetation, influencing the terrestrial processing of water before it reaches large rivers and their associated tributaries. The most consistent effect is that of increased peak flows 
during storm events because increased impervious surface area within watersheds, particularly connected impervious surfaces (Walsh et al. 2005, 2007), increases the efficiency of water transport within and between watersheds. The effects of increasing impervious surfaces extend beyond altering the water balance of small streams; urbanization is increasingly burying streams beneath impervious surface cover.

Buried streams may be small headwater channels that are simply paved over for parking lots, roads, and buildings, or they can be larger intermittent and perennial streams that are put into storm drains to efficiently transport water out of the watershed (Fig. $6)$. A recent example of this is provided by Elmore and Kaushal (2008): approximately $20 \%$ of stream miles in a major tributary of Chesapeake Bay are buried because of urbanization. This results in amplifying the effects of nitrogen transport during storm conditions when the terrestrial-aquatic interface is bypassed via direct flow to streams from urbanizing watersheds (Kaushal et al. 2008a). Buried streams differ from intact streams in many key aspects. Most importantly, flowing water does not generally make contact with hotspots of denitrification in biologically active soil (Groffman et al. 2002). Soil microbial activity is an important pathway of denitrification and therefore contributes to nitrogen retention. Further, considerable denitrification can occur where streamwater interacts with groundwater in the hyporheic zone (Kaushal et al. 2008b). In a buried stream, this interaction may be minimal to nonexistent. Small amounts of groundwater and hydrological exchange with surrounding soils may occur in buried streams, but it is typically perceived as a one-way process, with groundwater contributions to buried streams being exported efficiently.

In addition to headwater stream burial, the spread of development along the river corridor has resulted in substantial loss of riparian forest vegetation in the PRB (Sprague et al. 2006), enhancing the transfer of stormwater across riparian zones and circumventing terrestrial buffering capabilities. The interaction between the river and its floodplain is an important component of a normally functioning system. Development along waterways can have disproportionately large effects on aquatic systems, even though the development may represent a relatively small source of nutrient loading compared to other sources within watersheds (Kaushal et al.
2006). In the lower PRB, riparian wetlands, including tidal freshwater marshes, are significant in terms of nutrient removal, but many of these wetlands have been lost to development, river channelization, dredging, and erosion. In the upper $\mathrm{PRB}$, the land-river ecotone is particularly important to watershed nitrogen export (Jaworski 1993). At the landscape scale, the reduced hydrological exchange between a river, its floodplain, and shallow groundwater-influenced hyporheic soils can lead to increases in nutrient and pollutant transport downstream (Mitsch et al. 2001, Stanley and Doyle 2002, Forshay and Stanley 2005, Kaushal et al. 2008b). Thus, modern patterns of land-use change redistribute materials, simultaneously increasing hydrological connectivity via faster and more concentrated transport, yet essentially cutting off connectivity in other portions of the uplands. As a consequence, large rivers with impacted headwater streams and large downstream population centers may show permanently altered hydrology, nutrient and contaminant concentrations, and biota; it is only by studying the basin as a whole, i.e., both stream and watershed, that the causative forces behind these changes can be identified.

\section{THE RIVER AHEAD}

Water management policy has struggled for years with the disconnect between political and economic boundaries (the decision units) and relevant ecological boundaries (Reuss 2005). Scale mismatches between governance systems and natural resources (Borowski et al. 2008) tend to limit the ability to make meaningful progress in reducing local and transboundary effects. Decisions regarding zoning and land-use change are made at local scales, with little attention paid to cumulative consequences on water quantity and quality across city, county, and sometimes state borders. Such geopolitical disconnections inhibit or delay the response time for effective policies so that they are now slower than the rapid pace of environmental change. Recent advances in management are tending away from purely top-down command and control approaches to the more integrated participatory approaches that encourage social learning and stakeholder involvement (Pahl-Wostl et al. 2007). However, even these managerial advances are limited because of the multifaceted nature of water resource management, which operates at multiple spatial and temporal scales. 
Fig. 6. Estimates of stream burial for a rapidly developing region within the Potomac River basin north of Washington, D.C.

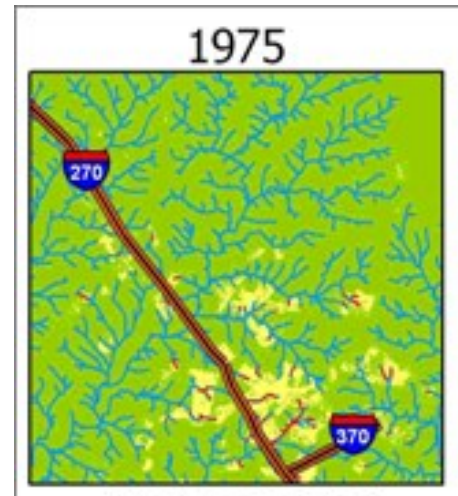

$4 \%$ Stream Burial

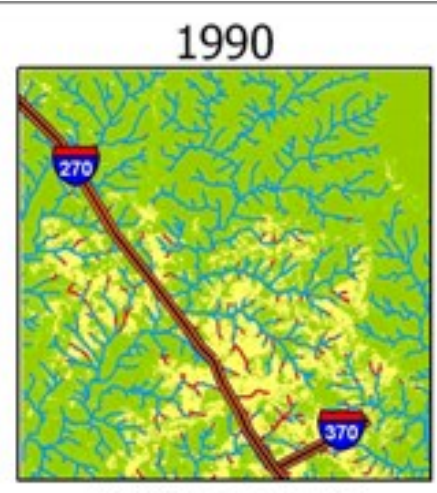

$10 \%$ Stream Burial

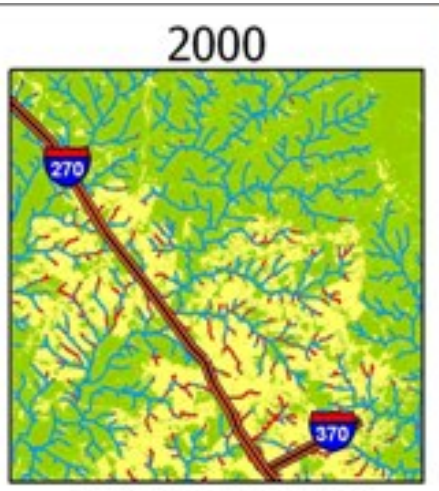

$17 \%$ Stream Burial

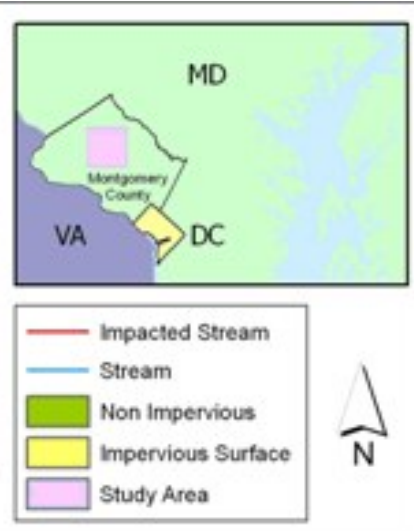

There is increasing interest in blurred boundaries at various scales (Post et al. 2007, Peters et al. 2008, Raadgever et al. 2008). The examples that we have provided for the PRB suggest that there is no magic scale for managing the hydrological consequences of land-use change. The blurring of boundaries at all scales means that the concept of a discrete selfcontained system is becoming increasingly obsolete for management purposes. Instead, responding to altered lateral fluxes such as changes in the quantity, form, and metabolism of nutrients; commuters' movement of waste and other materials; storage and piping of river water for domestic use; and loss of floodplain attenuation and subsequent increased transport of nutrients and sediments requires a comprehensive and interdisciplinary management strategy that includes an explicit accounting of transboundary fluxes.

Although large basins, as ecological units, may still exhibit substantial lateral transfer at their boundaries, their large size enables the integration of local patterns at a scale that corresponds to many human activities and management opportunities. The adoption of a small-watershed perspective has been successful in enhancing the understanding of stream chemistry dynamics under controlled conditions (e.g., Likens and Bormann 1977) and in urban watersheds (e.g., Baker et al. 2001, Weller et al. 2003, Groffman et al. 2004, Wollheim et al. 2005). A broader scale assessment is useful, however, in understanding many of the complex interactions between land-use decisions, hydrology, and biogeochemistry. For example, we have shown that human diversions within the PRB have resulted in a tripling of low flows for some watersheds and up to a $50 \%$ decrease in low flows for other parts of the basin. Linkages between finer-scale studies and new studies at larger scales are strongly needed to understand the relationships between human modifications of the landscape and ecological conditions for many streams and large rivers. Efficient water resource management depends upon this broader-scale understanding. For example, because nutrients can completely bypass riparian zones in urban watersheds, local restoration efforts that focus on riparian buffer vegetation will have limited effectiveness if the larger suite of potential inputs to a site is not addressed.

Emergent properties and nonlinear changes in system behavior may result from the increasing water and material inputs that arise from blurred boundaries and enhanced lateral transports. For example, land-use change may result in water being piped downstream during high flow conditions, with very little potential for in-stream processing (Bernot and Dodds 2005, Grimm et al. 2005). Alternatively, the pumping of water or import of contaminants across watershed boundaries may result in contaminant loads that exceed threshold tolerances for normal biogeochemical functioning 
Fig. 7. Patterns in total nitrogen point source loads in the Patuxent River (adapted from Boynton et al. 2008). Significant reductions in sewage treatment plant discharges occurred following the 1991 initiation of biological nitrogen removal (BNR) during warm-weather months (April-October). Recent increases in loads are due predominantly to expansion of residential hook-ups to sewage treatment plant facilities.

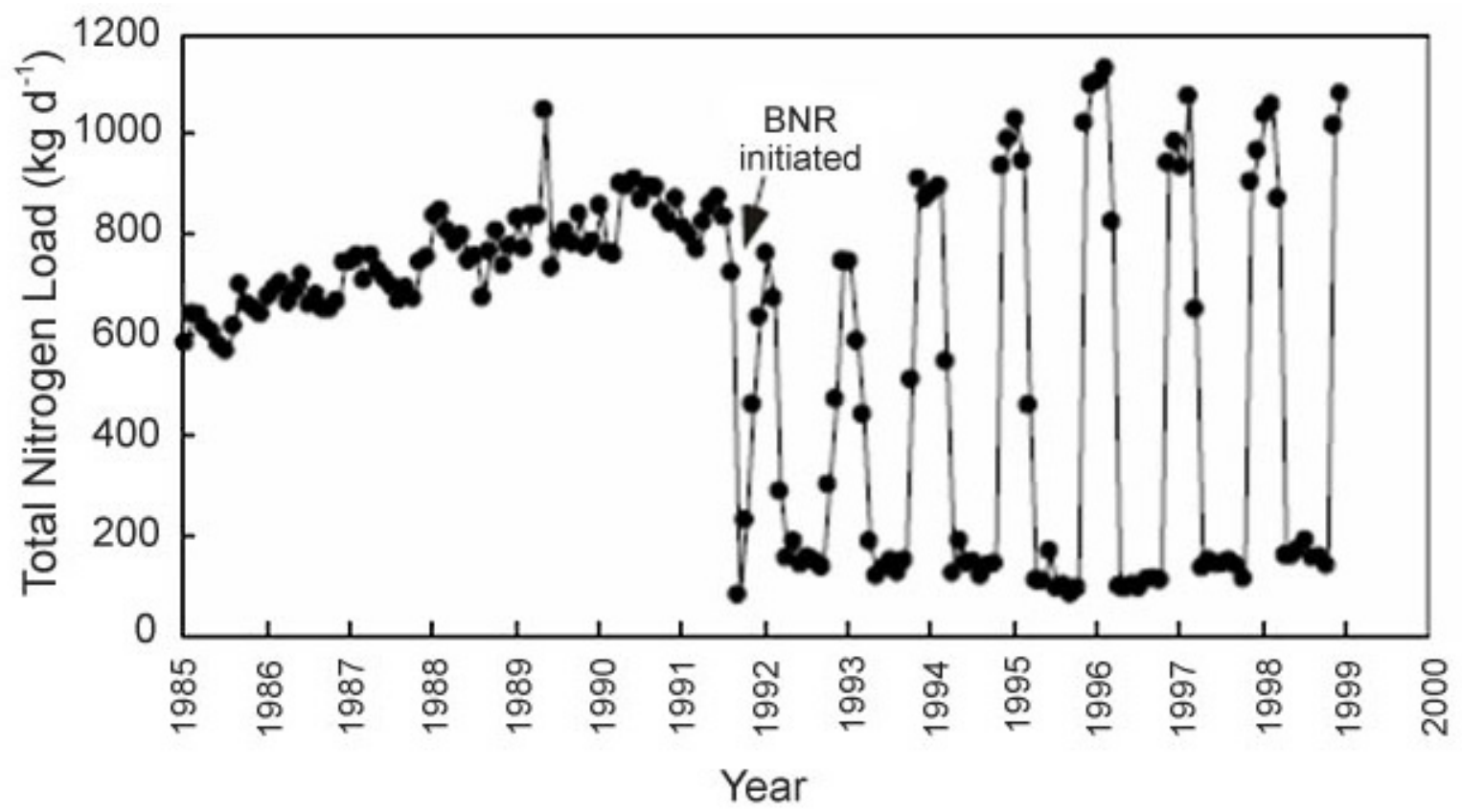

(Lowrance et al. 1997, Forshay and Stanley 2005). The identification and tracking of these nonlinear relationships require long-term investment in monitoring that is designed to capture spatial and temporal variability in human activities. Flexible monitoring designs that allow increased sampling intensity in response to early signs of system change would be useful to detect thresholds in long-term trends. Unfortunately, monitoring programs of large river systems, including those of the U.S. Geological Survey, have received decreasing support in recent years (Hirsch et al. 2006).

Additional scientific studies are also needed to quantify the different types of lateral flux associated with human movement over daily to decadal timescales. An integrated catchment approach can address these types of questions by bringing together the disciplines of landscape ecology, i.e., where urbanization is occurring and how it affects the spatial arrangement of natural resources; sociology, i.e., what natural amenities people value and what determines behavior with respect to these cultural values; economics, i.e., how natural resources can be valued quantitatively and how economic activity drives patterns of urbanization; and biogeochemistry, i.e., how urbanization affects chemical reactions and pollutant transport to receiving water bodies such as Chesapeake Bay.

This large-basin, integrated approach to the science would provide guidance to society, which can no longer afford to think only locally for its environmental management solutions. The reality of blurred boundaries and interbasin transfers requires not just a new approach to science and monitoring, but broad citizen awareness about the importance of upstream activities on downstream conditions and vise versa. Although recent water policy decisions have had some success in reducing local contaminant loading, these successes generally have not translated directly into improved 
conditions for large rivers. For example, in the neaby Patuxent River, nitrogen loads decreased in the 1990s as a result of improved waste water treatment practices and regulation of point sources. Biological nutrient removal technology now operates at sewage treatment plants in the basin from April through October, resulting in substantial decreases in nitrogen concentrations from these facilities and lower total loads in the river during warm weather months (Fig. 7). However, these point source reductions are now being overwhelmed by changes in nonpoint sources as suburban and urban areas expand at rapid rates (Langland et al. 2004), and there has been a pattern of increasing nitrogen loads in the river in recent years, primarily because of increased transport from nonpoint sources such as lawns, impervious surfaces, pet excrement, and others.

The continuing high nutrient loads, despite reductions in point sources, to the Potomac River estuary and other nearby estuaries have resulted in increasing volumes of water with low oxygen concentrations and the increasing prevalence of dead zones within Chesapeake Bay (Hagy et al. 2004, Kemp et al. 2005, Fisher et al. 2006). In response to its declining health, the Chesapeake Bay watershed leads the nation in the cost and number of stream restoration projects undertaken per kilometer of river since 1990 (Bernhardt et al. 2005, Hassett et al. 2005). The overwhelming majority of Chesapeake Bay restoration dollars are spent on the restoration of coastal areas adjacent to the bay, with considerably fewer projects focused on restoration efforts linking upland watersheds with streams and rivers. Because water, sediment, nutrients, and chemicals are increasingly mobile, a whole-basin approach to restoration could help to reduce the discouraging trends in contaminant loading for Chesapeake Bay and the Potomac River (Palmer 2009). This approach may involve increased funding for restoration efforts and stormwater management in upper parts of the watershed, in addition to local stream, riparian, and coastal restoration efforts in urban core areas at large river outlets.

\section{CONCLUSIONS}

During the past several decades, the widespread effects of acid rain, ozone depletion, and global climate change have served as major impetus for understanding ecosystem-level processes and the creation of regional and national policies (e.g., Likens and Bormann 1974, Aber et al. 1989, Keeling et al. 1995, Vitousek et al. 1997, Intergovernmental Panel on Climate Change 2007). However, these particular disturbances are mainly associated with atmospheric pollution and typically represent a vertical perspective in understanding environmental change. Considering humans as major transporters of nutrients within and between watersheds requires more detailed information on the demographics of watershed inhabitants, their mobility, and their behavior. Initiating studies with a more horizontal perspective is likely to be a far more interdisciplinary process than has previously been undertaken, but offers the best hope of understanding the novel fluxes of energy and materials that have increasingly come to characterize large river ecosystems in postindustrial landscapes.

Responses to this article can be read online at:

http://www.ecologyandsociety.org/voll4/iss2/art10/ responses/

\section{Acknowledgments:}

Dr. Dave Theobold graciously provided projections of urban development for the mid-Atlantic United States. The manuscript benefited from comments by Dr. Jason Julian. J. B. Churchill, Brian McCormick, and Steven Guinn provided assistance with graphics. This paper is scientific contribution number 4307 from the University of Maryland Center for Environmental Science; we acknowledge the many stimulating conversations with UMCES colleagues that contributed to its intellectual content. 


\section{LITERATURE CITED}

Aber, J. D., K. J. Nadelhoffer, P. Steudler, and J. M. Melillo. 1989. Nitrogen saturation in northern forest ecosystems. Bioscience 39:378-386.

Alexander, R. B., E. W. Boyer, R. A. Smith, G. E. Schwartz, and R. B. Moore. 2007. The role of headwater streams in downstream water quality. Journal of the American Water Resources Association 43(1):41-59.

Allan, J.A. 1998. Virtual water: a strategic resource global solutions to regional deficits. Ground Water 36(4):545-546.

Ator, S. W., J. D. Blomquist, J. W. Brakebill, J. M. Denis, M. J. Ferrari, C. V. Miller, and $\mathbf{H}$. Zappia. 1998. Water quality in the Potomac River Basin - Maryland, Pennsylvania, Virginia, West Virginia, and the District of Columbia, 1992-96. U. S. Geological Survey Circular 1166. Available online at: http://pubs.usgs.gov/circ/circ1166/.

Baker, L. A., P. M. Hartzheim, S. E. Hobbie, J. Y. King, and K. C. Nelson. 2007. Effect of consumption choices on fluxes of carbon, nitrogen and phosphorus through households. Urban Ecosystems 10(2):97-117.

Baker, L. A., D. Hope, Y. Xu, J. Edmonds, and L. Lauver. 2001. Nitrogen balance for the central Arizona-Phoenix (CAP) ecosystem. Ecosystems 4 (6):582-602.

Barnhart, J. D. 1931. Recent industrial growth and politics in the southern Appalachian region. Mississippi Valley Historical Review 17:581-594.

Benitez, J. A., and T. R. Fisher. 2004. Historical land-cover conversion (1665-1820) in the Choptank watershed, eastern United States. Ecosystems 7(3):219-232.

Bernhardt, E. S., M. A. Palmer, J. D. Allan, G. Alexander, K. Barnas, S. Brooks, J. Carr, S. Clayton, C. Dahm, J. Follstad-Shah, D. Galat, S. Gloss, P. Goodwin, D. Hart, B. Hassett, R. Jenkinson, S. Katz, G. M. Kondolf, P. S. Lake, R. Lave, J. L. Meyer, T. K. O'Donnell, L. Pagano, B. Powell, and E. Sudduth. 2005. Synthesizing U. S. river restoration efforts. Science 308:636-637.

Bernot, M. J., and W. K. Dodds. 2005. Nitrogen retention, removal, and saturation in lotic ecosystems. Ecosystems 8(4):442-453.

Blais, J. M., R. W. Macdonald, D. Mackay, E. Webster, C. Harvey, and J. P. Smol. 2007. Biologically mediated transport of contaminants to aquatic systems. Environmental Science \& Technology 41(4): 1075-1084.

Boesch, D. F., and J. Greer. 2003. Chesapeake futures. STAC Pub. 03-001. Chesapeake Research Consortium, Edgewater, Maryland, USA.

Borowski,I., J.-P.Le Bourhis, C. Pahl-Wostl, and B. Barraqué. 2008. Spatial misfit in participatory river basin management: effects on social learning, a comparative analysis of German and French case studies. Ecology and Society 13(1): 7. [online] URL: http://www.ecologyandsociety.org/vol13/iss1/art7/

Boyer, E. W., C. L. Goodale, N. A. Jaworski, and R. W. Howarth. 2002. Anthropogenic nitrogen sources and relationships to riverine nitrogen export in the northeastern U.S.A. Biogeochemistry 57-58: $137-169$.

Boynton, W. R., J. D. Hagy, J. C. Cornwell, W. M.Kemp, S. M. Greene, M.S. Owens, J. E. Baker, and R. K. Larsen. 2008. Nutrient budgets and management actions in the Patuxent River estuary, Maryland. Estuaries and Coasts 31(4):623-651.

Brandes, D., G. J. Cavallo, and M. L. Nilson. 2005. Base flow trends in urbanizing watersheds of the Delaware River basin. Journal of the American Water Resources Association 41(6): 1377-1391.

Carpenter, D. H., and D. C. Hayes. 1996. Lowflow characteristics of streams in Maryland and Delaware. Water-Resources Investigations Report 94-4020. U.S. Geological Survey, Towson, Maryland, USA.

Cohn, J. P. 2004. The wildest urban river: Potomac River gorge. Bioscience 54(1):8-14.

Driscoll, C. T., D. Whitall, J. Aber, E. Boyer, M. Castro, C. Cronan, C. L. Goodale, P. Groffman, C. Hopkinson, K. Lambert, G. Lawrence, and S. Ollinger. 2003. Nitrogen pollution in the northeastern United States: sources, effects, and management options. Bioscience 53(4):357-374. 
Elmore, A. J., and S. S. Kaushal. 2008. Disappearing headwaters: patterns of stream burial due to urbanization. Frontiers in Ecology and Environment 6(6):308-312.

Fisher, T. R., J. D. Hagy III, W. R. Boynton, and M. R. Williams. 2006. Cultural eutrophication in the Choptank and Patuxent estuaries of Chesapeake Bay. Limnology and Oceanography 51(1/2):435-447.

Foley, J. A., R. DeFries, G. P. Asner, C. Barford, G. Bonan, S. R. Carpenter, F. S. Chapin, M. T. Coe, G. C. Daily, H. K. Gibbs, J. H. Helkowski, T. Holloway, E. A. Howard, C. J. Kucharik, C. Monfreda, J. A. Patz, I. C. Prentice, N. Ramankutty, and P. K. Snyder. 2005. Global consequences of land use. Science 309:570-574.

Forshay, K. J., and E. H. Stanley. 2005. Rapid nitrate loss and denitrification in a temperate river floodplain. Biogeochemistry 75(1):43-64.

Galster, G., R. Hanson, M. R. Ratcliffe, H. Wolman, S. Coleman, and J. Freihage. 2001. Wrestling sprawl to the ground: defining and measuring an elusive concept. Housing Policy Debate 12(4):681-717.

Goetz, S. J., C. A. Jantz, S. D. Prince, A. J. Smith, D. Varlyguin, and R. K. Wright. 2004. Integrated analysis of ecosystem interactions with land use change: the Chesapeake Bay watershed. Pages 263-275 in R. S. DeFries, G. P. Asner, and R. A. Houghton, editors. Ecosystems and land use change. American Geophysical Union, Washington, D.C., USA.

Grimm, N. B., R. W. Sheibly, C. L. Crenshaw, C. N. Dahm, W. J. Roach, and L. H. Zeglin. 2005. N retention and transformation in urban streams. Journal of the North American Benthological Society 24(3):626-642.

Groffman, P. M., N. J. Boulware, W. C. Zipperer, R. V. Pouyat, L. E. Band, and M. F. Colosimo. 2002. Soil nitrogen cycle processes in urban riparian zones. Environmental Science \& Technology 36 (21):4547-4552.

Groffman, P. M., N. L. Law, K. T. Belt, L. E. Band, and G. T. Fisher. 2004. Nitrogen fluxes and retention in urban watershed ecosystems. Ecosystems 7(4):393-403.

Hagen, E. R., and R. C. Steiner. 2000. Year 2000: twenty-year demand forecast and resource availability analysis for the Washington metropolitan area. ICPRB Report 00-6. Interstate Commission on the Potomac River Basin, Rockville, Maryland, USA.

Hagy, J. D., W. R. Boynton, C. W. Keefe, and K. V. Wood. 2004. Hypoxia in Chesapeake Bay, 19502001: long-term change in relation to nutrient loading and river flow. Estuaries 27:634-658.

Hassett, B., M. Palmer, E. Bernhardt, S. Smith, J. Carr, and D. Hart. 2005. Restoring watersheds project by project: trends in Chesapeake Bay tributary restoration. Frontiers in Ecology and the Environment 3(5):259-267.

Hatch, L. K., A. Mallawatantri, D. Wheeler, A. Gleason, D. Mulla, J. Perry, K. W. Easter, R. Smith, L. Gerlach, and P. Brezonik. 2001. Land management at the major watershed-agroecoregion intersection. Journal of Soil and Water Conservation 56(1):44-51.

High, M. 1997. The C\&O Canal companion. Johns Hopkins University Press, Baltimore, Maryland, USA.

Hirsch, R. M., P. A. Hamilton, and T. L. Miller. 2006. U.S. Geological Survey perspective on waterquality monitoring and assessment. Journal of Environmental Monitoring 8(5):512-518.

Hoekstra, A. Y., and A. K. Chapagain. 2007. Water footprints of nations: water use by people as a function of their consumption pattern. Water Resources Management 21(1):35-48.

Intergovernmental Panel on Climate Change. 2007. Climate change 2007: the physical science basis. Contribution of Working Group I to the fourth assessment. S. Solomon, D. Qin, M. Manning, Z. Chen, M. Marquis, K. B. Averyt, M. Tignor, and H. L. Miller, editors. Cambridge University Press, Cambridge, UK.

Irwin, E. G., and N. E. Bockstael. 2002. Interacting agents, spatial externalities and the evolution of residential land use patterns. Journal of Economic Geography 2(1):31-54.

Jaworski, N. A. 1990. Retrospective study of the water quality issues of the upper Potomac estuary. Reviews in Aquatic Sciences 3(1):11-40. 
Jaworski, N. A. 1993. The application of the ecotone concept in defining nutrient management requirements for the upper Potomac River basin. Hydrobiologia 251(1-3):341-349.

Jaworski, N. A., P. M. Groffman, A. A. Keller, and J. C. Prager. 1992. A watershed nitrogen and phosphorus balance: the upper Potomac River basin. Estuaries 15(1):83-95.

Jordan, T. E., and D. E. Weller. 1996. Human contributions to terrestrial nitrogen flux. Bioscience 46:655-664.

Kaushal, S. S., P. M. Groffman, L. E. Band, C. A. Shields, R. P. Morgan, M. A. Palmer, K. T. Belt, C. M. Swan, S. E. G. Findlay, and G. T. Fisher. 2008a. Interaction between urbanization and climate variability amplifies watershed nitrate export in Maryland. Environmental Science \& Technology 42(16):5872-5878.

Kaushal, S. S., P. M. Groffman, P. M. Mayer, E. Striz, and A. J. Gold. 2008b. Effects of stream restoration on denitrification in an urbanizing watershed. Ecological Applications 18(3):789-804.

Kaushal, S. S., W. M. Lewis, Jr., and J. H. McCutchan, Jr. 2006. Land use change and nitrogen enrichment of a Rocky Mountain watershed. Ecological Applications 16(1):299-312.

Keeling, C. D., T. P. Whorf, M. Wahlen, and J. Van der Plichtt. 1995. Interannual extremes in the rate of rise of atmospheric carbon dioxide since 1980. Nature 375:666-670.

Kemp, W. M., W. R. Boynton, J. E. Adolf, D. F. Boesch, W. C. Boicourt, G. Brush, J. C. Cornwell, T. R. Fisher, P. M. Glibert, J. D. Hagy, L. W. Harding, E. D. Houde, D. G. Kimmel, W. D. Miller, R. I. E. Newell, M. R. Roman, E. M. Smith, and J. C. Stevenson. 2005. Eutrophication of Chesapeake Bay: historical trends and ecological interactions. Marine Ecology Progress Series 303:1-29.

Kennedy, C., J. Cuddihy, and J. Engel-Yan. 2007. The changing metabolism of cities. Journal of Industrial Ecology 11(2):43-59.

Kenworthy, J. R., and F. B. Laube. 1999. An international sourcebook of automobile dependence in cities, 1960-1990. University Press of Colorado, Boulder, Colorado, USA.

Langland, M. J., S. W. Phillips, J. P. Raffensperger, and D. L. Moyer. 2004. Changes in streamflow and water quality in selected nontidal sites in the Chesapeake Bay basin, 1985-2003. U. S. Geological Survey, Reston, Virginia, USA. Available online at: http://purl.access.gpo.gov/GPO/ LPS57336.

Lankao, P. R. 2004. Pathways of regional development and the carbon cycle. Pages 355-370 in C. B. Field and M. R. Raupach, editors. The global carbon cycle: integrating humans, climate and the natural world. Island Press, Washington, D.C., USA.

Likens, G. E., and F. H. Bormann. 1974. Acid rain: a serious regional environmental problem. Science 184: 1176-1179.

Likens, G. E., and F. H. Bormann. 1977. Biogeochemistry of a forested ecosystem. SpringerVerlag, New York, New York, USA.

Lowrance, R., L. S. Altier, J. D. Newbold, R. R. Schnabel, P. M. Groffman, J. M. Denver, D. L. Correll, J. W. Gilliam, J. L. Robinson, R. B. Brinsfield, K. W. Staver, W. Lucas, and A. H. Todd. 1997. Water quality functions of riparian forest buffers in Chesapeake Bay watersheds. Environmental Management 21(5):687-712.

Magner, J. A., and K. N. Brooks. 2008. Integrating sentinel watershed-systems into the monitoring and assessment of Minnesota's (USA) waters quality. Environmental Monitoring and Assessment 138 (1-3):149-158.

Meyerson, F. A. B., L. Merino, and J. Durand. 2007. Migration and environment in the context of globalization. Frontiers in Ecology and Environment 5(4):182-190.

Mikkelsen, R. L., and T. W. Bruulsema. 2005. Fertilizer use for horticultural crops in the U.S. during the 20th century. HortTechnology $\mathbf{1 5}$ (1):24-30.

Miller, E. J., and A. Ibrahim. 1998. Urban form and vehicular travel: some empirical findings. Transportation Research Record 1617:18-27. 
Mitsch, W. J., J. W. Day, Jr., J. W. Gilliam, P. M. Groffman, D. L. Hey, G. W. Randall, and N. M. Wang. 2001. Reducing nitrogen loading to the Gulf of Mexico from the Mississippi River basin: strategies to counter a persistent ecological problem. Bioscience 51:373-388.

Morrill, R. 2006. Classic map revisited: the growth of megalopolis. Professional Geographer $\mathbf{5 8}$ (2):155-160.

Mustard, J. F., R. S. DeFries, T. Fisher, and E. Moran. 2005. Land-use and land-cover change pathways and impacts. Pages 411-429 in G. Gutman, A. C. Janetos, C. O. Justice, E. F. Moran, J. F. Mustard, R. R. Rindfuss, D. Skole, B. L. Turner II, and M. A. Cochran, editors. Land change science: observing, monitoring and understanding trajectories of change on the Earth's surface. Kluwer, Dordrecht, The Netherlands.

Nadeau, T.-L., and M. C. Rains. 2007. Hydrological connectivity between headwater streams and downstream waters: how science can inform policy. Journal of the American Water Resources Association 43(1):118-133.

Nilsson, C., J. E. Pizzuto, G. E. Moglen, M. A. Palmer, E. H. Stanley, N. E. Bockstael, and L. C. Thompson. 2003. Ecological forecasting and the urbanization of stream ecosystems: challenges for economists, hydrologists, geomorphologists, and ecologists. Ecosystems 6(7):659-674.

Otterstrom, S. M. 2003. Population concentration in United States city-systems from 1790 to 2000: historical trends and current phases. Tijdschrift voor Economische en Sociale Geografie 94(4):477-495.

Pahl-Wostl, C., M. Craps, A. Dewulf, E. Mostert, D. Tabara, and T. Taillieu. 2007. Social learning and water resources management. Ecology and Society 12(2): 5. [online] URL: http://www.ecology andsociety.org/vol12/iss2/art5.

Palmer, M. A. 2009. Reforming watershed restoration: science in need of application and applications in need of science. Estuaries and Coasts 32(1):1-17.

Paul, M. J., and J. L. Meyer. 2001. Streams in the urban landscape. Annual Review of Ecology and Systematics 32:333-365.
Peters, D. P. C., P. M. Groffman, K. J. Nadelhoffer, N. B. Grimm, S. L. Collins, W. K. Michener, and M. A. Huston. 2008. Living in an increasingly connected world: a framework for continental-scale environmental science. Frontiers in Ecology and the Environment 6(5):229-237.

Pickett, S. T. A., M. L. Cadenasso, J. M. Grove, C. H. Nilon, R. V. Pouyat, W. C. Zipperer, and R. Costanza. 2001. Urban ecological systems: linking terrestrial ecological, physical, and socioeconomic components of metropolitan areas. Annual Review of Ecology and Systematics 32:127-157.

Post, D. M., M. W. Doyle, J. L. Sabo, and J. C. Finlay. 2007. The problem of boundaries in defining ecosystems: a potential landmine for uniting geomorphology and ecology. Geomorphology 89(1-2):111-126.

Postel, S. L. 2000. Entering an era of water scarcity: the challenges ahead. Ecological Applications $\mathbf{1 0}$ (4):941-948.

Postel, S. L., G. C. Daily, and P. R. Ehrlich. 1996. Human appropriation of renewable fresh water. Science 271:785-788.

Preuss, I., and A. W. Vemuri. 2004. "Smart growth" and dynamic modeling: implications for quality of life in Montgomery County, Maryland. Ecological Modelling 171(4):415-432.

Raadgever, G. T., E. Mostert, N. Kranz, E. Interwies, and J. G. Zimmerman. 2008. Assessing management regimes in transboundary river basins: Do they support adaptive management? Ecology and Society 13(1): 14. [online] URL: http: //www.ecologyandsociety.org/vol13/iss1/art14/.

Reuss, M. 2005. Ecology, planning, and river management in the United States: some historical reflections. Ecology and Society 10: 34. [online] URL: http://www.ecologyandsociety.org/vol10/iss1/ art34/.

Schröter, D., W. Cramer, R. Leemans, I. C. Prentice, M. B.Araújo, N. W.Arnell, A. Bondeau, H. Bugmann, T. R. Carter, C. A. Gracia, A. C. de la Vega-Leinert, M. Erhard, F. Ewert, M. Glendining, J. I. House, S. Kankaanpää, R. J. T. Klein, S. Lavorel, M. Lindner, M. J. Metzger, J. Meyer, T. D. Mitchell, I. Reginster, M. 
Rounsevell, S. Sabaté, S. Sitch, B. Smith, J. Smith, P. Smith, M. T. Sykes, K. Thonicke, W. Thuiller, G. Tuck, S. Zaehle, and B. Zierl. 2005. Ecosystem service supply and vulnerability to global change in Europe. Science 310:1333-1337.

Simmons, D. L., and R. J. Reynolds. 1982. Effects of urbanization on base flow of selected south-shore streams, Long Island, New York. Water Resources Bulletin 18(5):797-805.

Sprague, E., D. Burke, S. Claggett, and A. Todd, editors. 2006. The state of Chesapeake forests. Conservation Fund and USDA Forest Service, Arlington, Virginia, USA. Available online at: ww w.na.fs.fed.us/watershed/pdf/socf/Table $\% 20$ of\% 20Contents\&Prologue.pdf.

Stanley, E. H., and M. W. Doyle. 2002. A geomorphic perspective on nutrient retention following dam removal. Bioscience 52:693-701.

Steiner, R. C., E. R. Hagen, and J. Ducnuigeen. 2000. Water supply demands and resources analysis in the Potomac River basin. ICPRB Report 00-5. Interstate Commission on the Potomac River Basin, Rockville, Maryland, USA.

Sultana, S., and J. Weber. 2007. Journey-to-work patterns in the age of sprawl: evidence from two midsize southern metropolitan areas. Professional Geographer 59(2):193-208.

Theobald, D. M. 2001. Land-use dynamics beyond the American urban fringe. Geographical Review 91(3):544-564.

Turner, M. G. 2005. Landscape ecology in North America: past, present, and future. Ecology 86 (8):1967-1974.

United States Census Bureau. 2000. United States Census 2000. U.S. Department of Commerce, Washington, D.C., USA.

Valiela, I., G. Collins, J. Kremer, K. Lajtha, M. Geist, B. Seely, J. Brawley, and C. H. Sham. 1997. Nitrogen loading from coastal watersheds to receiving estuaries: new method and application. Ecological Applications 7(2):358-380.

Vitousek, P. M., J. D. Aber, R. W. Howarth, G. E. Likens, P. A. Matson, D. W. Schindler, W. H. Schlesinger, and D. G. Tilman. 1997. Human alteration of the global nitrogen cycle: sources and consequences. Ecological Applications 7(3):737-750.

Wackernagel, M., and W. E. Ress. 1996. Our ecological footprint: reducing human impact on the Earth. New Society Publishers, Gabriola Island, Canada.

Walling, D. E., and D. Fang. 2003. Recent trends in the suspended sediment loads of the world's rivers. Global and Planetary Change 39 (1-2):111-126.

Walsh, C. J., A. H. Roy, J. W. Feminella, P. D. Cottingham, P. M. Groffman, and R. P. Morgan II. 2005. The urban stream syndrome: current knowledge and the search for a cure. Journal of the North American Benthological Society $\mathbf{2 4}$ (3):706-723.

Walsh, C. J., K. A. Waller, J. Gehling, and R. MacNally. 2007. Riverine invertebrate assemblages are degraded more by catchment urbanisation than by riparian deforestation. Freshwater Biology 52 (3):574-587.

Weller, D. E., T. E. Jordan, D. L. Correll, and Z. J. Liu. 2003. Effects of land-use change on nutrient discharges from the Patuxent River watershed. Estuaries 26:244-266.

Wernick, B. G., K. E. Cook, and H. Schreier. 1998. Land use and streamwater nitrate-N dynamics in an urban-rural fringe watershed. Journal of the American Water Resources Association 34 (3):639-650.

Williamson, C. E., W. Dodds, T. K. Kratz, and M.A. Palmer. 2008. Lakes and streams as sentinels of environmental change in terrestrial and atmospheric processes. Frontiers in Ecology and the Environment 6(5):247-254.

Wines, R. A. 1985. Fertilizer in America: from waste recycling to resource exploitation. Temple University Press, Philadelphia, Pennsylvania, USA.

Wollheim, W. M., B. A. Pellerin, C. J. Vörösmarty, and C. S. Hopkinson. 2005. N retention in urbanizing headwater catchments. Ecosystems 8(8):871-884.

Wolman, A. 1965. The metabolism of cities. Scientific American 213(2):179-190. 